\title{
The use of gabbro dust in the cold recycling of asphalt paving mixes with foamed bitumen
}

\author{
M. IWAŃSKI*, P. BUCZYŃSKI, and G. MAZUREK \\ Civil Engineering and Architecture, Kielce University of Technology, 7 Tysiąclecia Państwa Polskiego Ave., 25-314 Kielce, Poland
}

\begin{abstract}
Mineral fines are a waste product of aggregate production in quarries and asphalt mixing plants. The incorporation of mineral gabbro dust into foam bitumen causes developing of a mesh reinforcement in the recycled base mixture. This mesh reinforcement, observed in a recycled base structure, induces an increase in stiffness modulus, where its elastic part of complex modulus dominates over the imaginary part. Therefore, it is possible to create a recycled mixture with a lower susceptibility to loading time/temperature. In result, the presence of gabbro dust in recycled mixture limits the magnitude of strains induced by the traffic load. This paper presents the results of the tests carried out on the mineral dusts derived from gabbro rock. Structural and functional properties of the fines were determined to prepare their characteristics. Then, the cold recycled mixtures for the road base were designed with the 5-20\% mineral fines content. The mixtures were prepared in cold recycling technology with foamed bitumen. Further tests involved determining mechanical and physical properties of the recycled mixes, including air voids content, Marshall stability, Marshall quotient (stiffness), indirect tensile strength and stiffness modulus at $20^{\circ} \mathrm{C}$ ). The results indicated a positive influence of the gabbro dusts on the investigated parameters. With the use of ANOVA tests, the significance of the influence of the gabbro dust and foamed bitumen on these properties was evaluated. Harrington's multicriteria method was employed to establish gabbro dust and foamed bitumen amounts, the addition of which would guarantee optimal properties of the recycled base mixture.
\end{abstract}

Key words: gabbro dust, cold recycling technology, foamed bitumen, road base course.

\section{Introduction}

The disposal, or utilization of the fines generated in industrial processes is difficult due to different grain size of the fines and their different chemical properties. In the past, the disposal of power plant fly ash produced from coal combustion was a major challenge for environmentalists and scientists. This problem has been addressed in numerous studies [1-4]. Recently, much attention has been paid to the utilization of mineral fines generated during the production of aggregates and the mixing of asphalt materials.

Dynamic development of road networks in Poland has increased a demand for high quality aggregate to be used in the production of pavement structural layers. One of the quality parameters to be taken into account is the reduced content of mineral dust. Its high content has a negative effect on the bitumen adhesion to the mineral grains, thus affecting the quality of the structural layers. According to the requirements set by [5] and [6], the amount of dust (particles smaller than $0.063 \mathrm{~mm}$ ) in the aggregate intended for wearing, binder and base courses should be within the range from 2 to $16 \%$, depending on the aggregate fraction. The maximum allowable content of mineral dust, characteristic of fine aggregate with $0-2 \mathrm{~mm}$ or $4 \mathrm{~mm}$ grain size, is $16 \%\left(\mathrm{f}_{16}\right)$. To ensure the critical limits of dust content, construction aggregate plants wash the aggregate, or (rarely) collect dust through dust extraction

*e-mail: iwanski@tu.kielce.pl systems, producing large amounts of waste product that is difficult to utilize.

It has to be noted that the quarries (rock material processing plants) are not the only producers of waste mineral dust. The requirements relating to assuring proper quality of asphalt mixes lead to further aggregate dedusting processes performed in the asphalt production plants. Mineral dust from these plants may vary by mineralogical origin, as asphalt mixes are manufactured with different types of aggregate [7, 8].

The use of mineral dust in the road construction industry is limited due to the variety of types of rock materials the dust is derived from. Only those that originate from limestone rock with a high content of calcium carbonate $\left(\mathrm{CaCO}_{3}\right)$ can be utilized as a replacement filler [9] or coal mining [10]. The application of dust derived from other rocks may lead to lowering the quality of pavement structure, thus reducing its durability.

The EU budget for 2014-2020 provides for considerable resources to be available for the development of the road infrastructure in Poland. Millions of tonnes of aggregate will be produced, and huge amounts of mineral dust will be generated, making its utilization a real problem.

A technology that will make use of mineral dusts, turning this problem into an opportunity, is yet to be developed. One of the possible solutions is using mineral dust in deep cold recycling of pavement structural layers with foamed bitumen, during which the base courses of restored or new pavements are constructed [11]. The mineral mixture used in this technology is characterized by a 5 to $20 \%$ content of mineral material passing through the $0.063 \mathrm{~mm}$ sieve [12]. This amount is much higher 
than that applied in the commonly used mineral-cement- emulsion mixtures $[13,14]$. In addition, a high content of fine fractions, present in the recycled mix with foamed bitumen, has been found to improve its quality, as the fine particles are bound by foamed bitumen, creating its internal structure, and ensuring a high quality of the recycled material $[15,16]$.

\section{Materials}

The tests aimed to evaluate the use of mineral dust in the deep cold recycling with foamed bitumen were carried out on the fines derived from gabbro rock $(\mathrm{G})$, produced in the process of dust extraction from aggregates during a drying operation, performed in an asphalt mix manufacturing facility. Owing to their good mechanical parameters, aggregates of this type are very often used to produce asphalt paving mixes for wearing courses. Gabbro dust is also produced as a result of washing the aggregate in the quarry. To identify the mineral fines, their basic structural and functional properties had to be determined [17].

Structural characteristics can be defined as a reflection of the fines' internal design, in other words, the distribution of their components (solid, liquid, and gaseous phases). The following structural characteristics were determined in the tests: gradation, specific surface $(\mathrm{PW})$, clay content $(\mathrm{MBF})$, and air void content (AVR).

Functional properties include a group of characteristics associated with the behavior and interaction of mineral fines in pastes. Bitumen absorption of mineral fillers (fines) is one of the basic functional properties. Another property, the $\mathrm{pH}$ number, is determined to identify acidity levels of the fillers. The results of the tests evaluating the structural characteristics of the gabbro dust are presented in Fig. 1.
The results of analysis of structural characteristics (Fig. 1) indicate that gabbro dusts have a large specific surface $\left(\mathrm{P}_{\mathrm{w}}=4709 \mathrm{~cm}^{2} / \mathrm{g}\right)$ according to [18], which will have a significant impact on the quality of the recycled mix. The value of the specific surface was determined from the degree of fineness. The value of MBF [19], i.e. the clay content in the material, indicates that the fines derived from the gabbro rock have low concentrations of clay minerals $(\mathrm{MBF}=3.3)$, thus having a beneficial effect on the bitumen adhesion to the mineral mixture in the process of the recycled mix production.

The air void content AVR [20] of dry compacted gabbro dust was ranging approximately from $56.4 \%$ to $57.2 \%$ (at a significant level of 0.05 ), which ensures that the fines will be properly coated by the bitumen.

The analysis of the photographs of the gabbro fines, obtained using the spraying method and a scanning microscope,

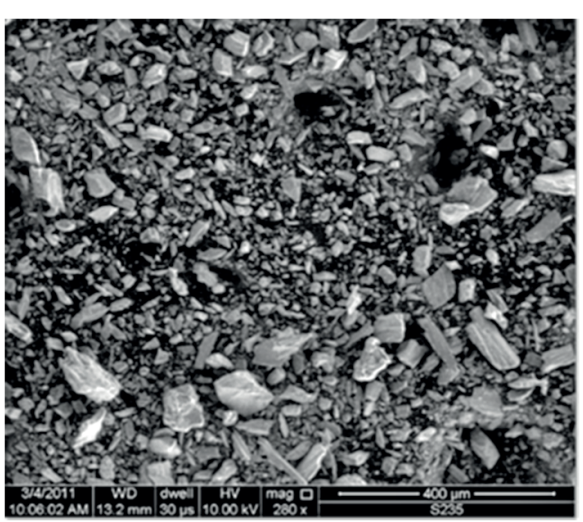

Fig. 2. Scanning image of gabbro dust gradation

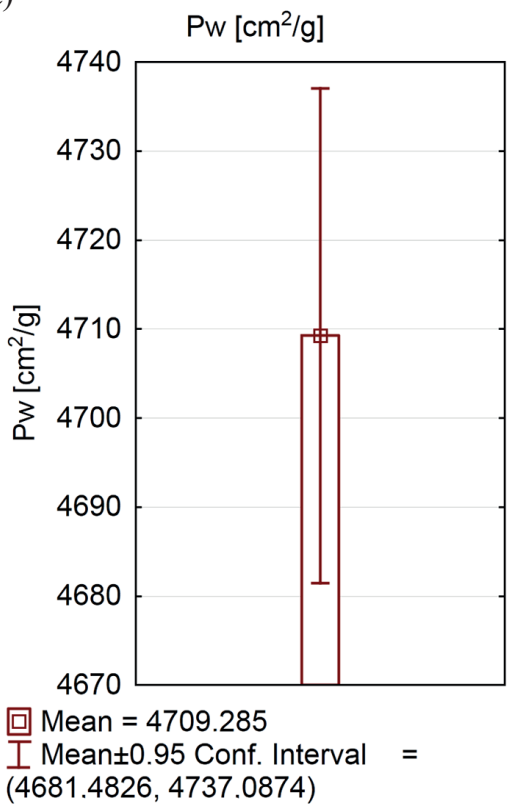

b)

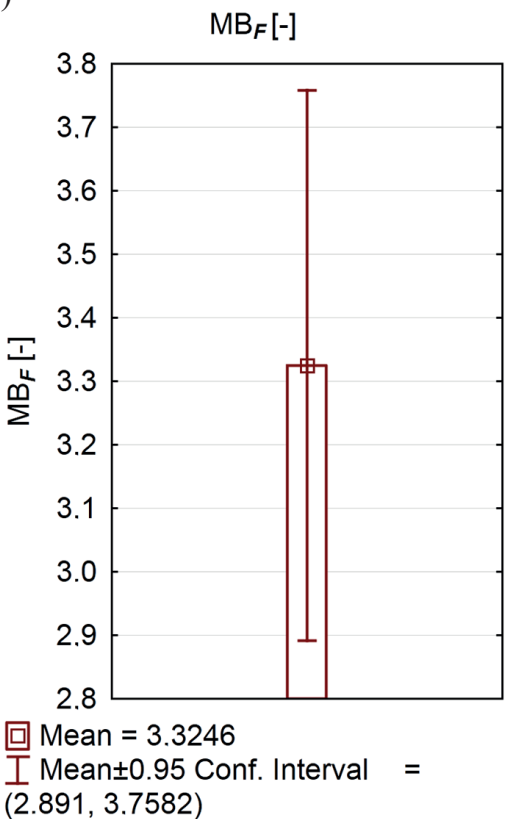

c)

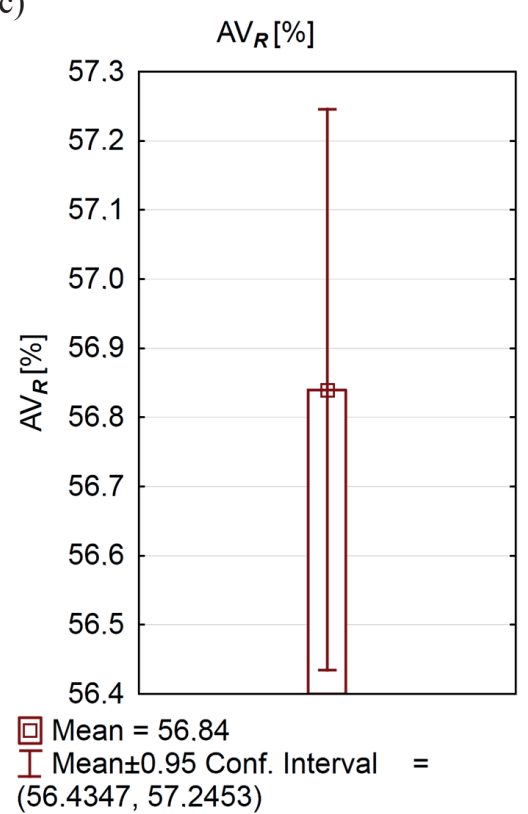

Fig. 1. Basic structural characteristics of gabbro dust: a) specific surface - Blaine, b) methylene blue index, c) air voids in dry compacted dust 
a)

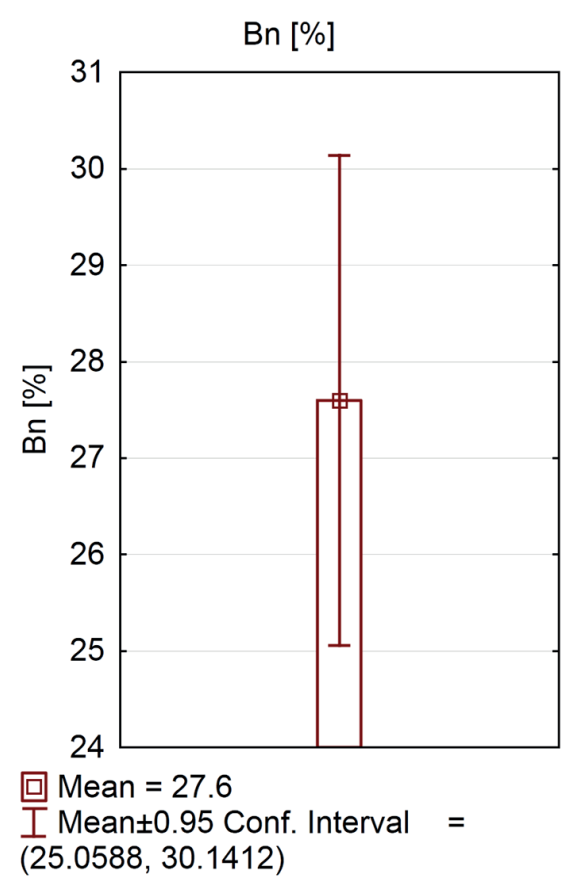

b)

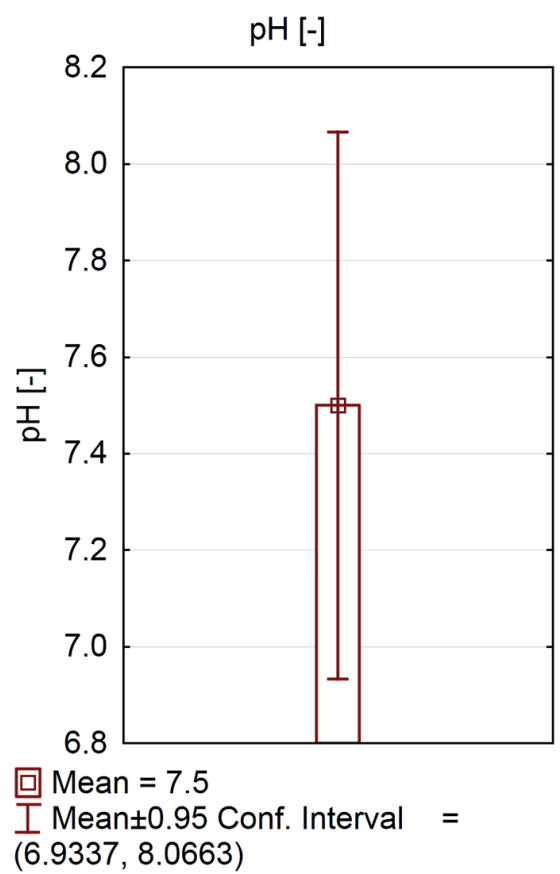

Fig. 3. Functional properties of gabbro dust: a) bitumen number, b) $\mathrm{pH}$ number

facilitates the evaluation of their gradation (Fig. 2). Mineral fines from gabbros usually range from $0.02-0.063 \mathrm{~mm}$ in size.

Determining the functional properties of mineral gabbro fines was the next step in the investigations (Fig. 3). Functional properties have a significant formative impact on the parameters of the bituminous composite.
The bitumen number, described by the gabbro dust viscosity level at a specified amount of water [21], indicates a medium level of this parameter $(\mathrm{BN}=27.6)$. The $\mathrm{pH}$ number greater than 7 indicates the alkaline character of the gabbro dust. The results confirm the fact that the investigated gabbros were derived from the crushed rock and did not contain any detrimental additions. The functional properties will thus favorably affect the recycled asphalt mixture by improving the bonding between the bitumen and the aggregate grains.

The quality of the binder is a critical factor. The requirement that has to be satisfied in deep cold recycling with foamed bitumen is the use of a bitumen with an adequate expansion coefficient (WE) and a proper half-life ( $\mathrm{t} 1 / 2)$ of the foam [22]. The bitumen used in this study, denoted as $80 \mathrm{~N}$ (Fig. 4), was selected on the basis of the values determined at the Kielce University of Technology [23].

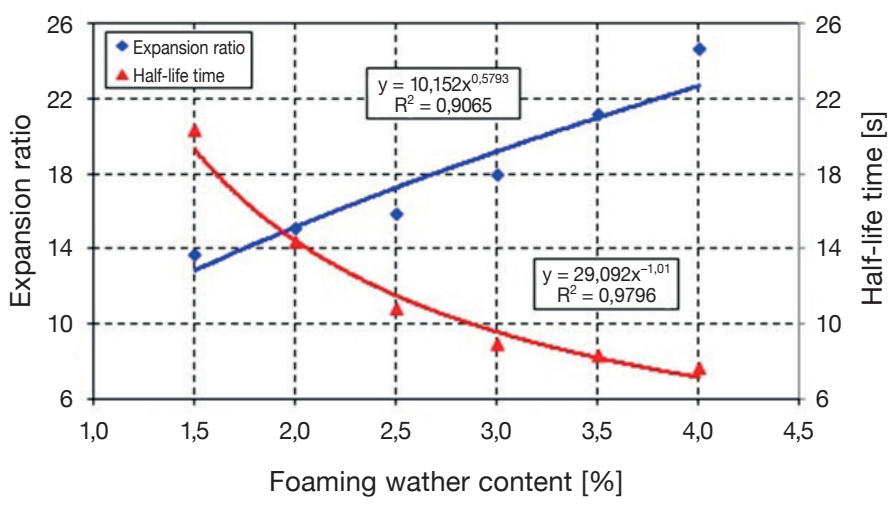

Fig. 4. Foamed bitumen characteristics for bitumen 80N [23]

The $80 \mathrm{~N}$ bitumen had the most beneficial foaming parameters (described in detail in [23]), with the expansion ratio of $\mathrm{WE}=15.1$ and the half-life of the foam $\mathrm{t}^{1} / 2=14.4 \mathrm{~s}$.

\section{Methodology}

To evaluate the suitability of the gabbro dust for the purposes of deep cold recycling with foamed bitumen, four paving mineral mixtures were designed to the requirements of [13], based on the optimal grading curve. All conducted tests were related to laboratory tests. Their results were the first step designated for planned field tests where deep cold recycling with foamed bitumen mixture with mineral dust was applied.

The design assumed the use of a maximum amount of the existing road material, and the maximum allowable amount of mineral dust. The mineral mixture of the recycled base course comprised 50-65\% reclaimed asphalt millings from structural layers, $30 \%$ aggregates with grain size up to $31.5 \mathrm{~mm}$ from the existing base course made of mechanically stabilized aggregate, and $5 \%, 10 \%, 15, \%$ and $20 \%$ of mineral dust (gabbro) for gra- 


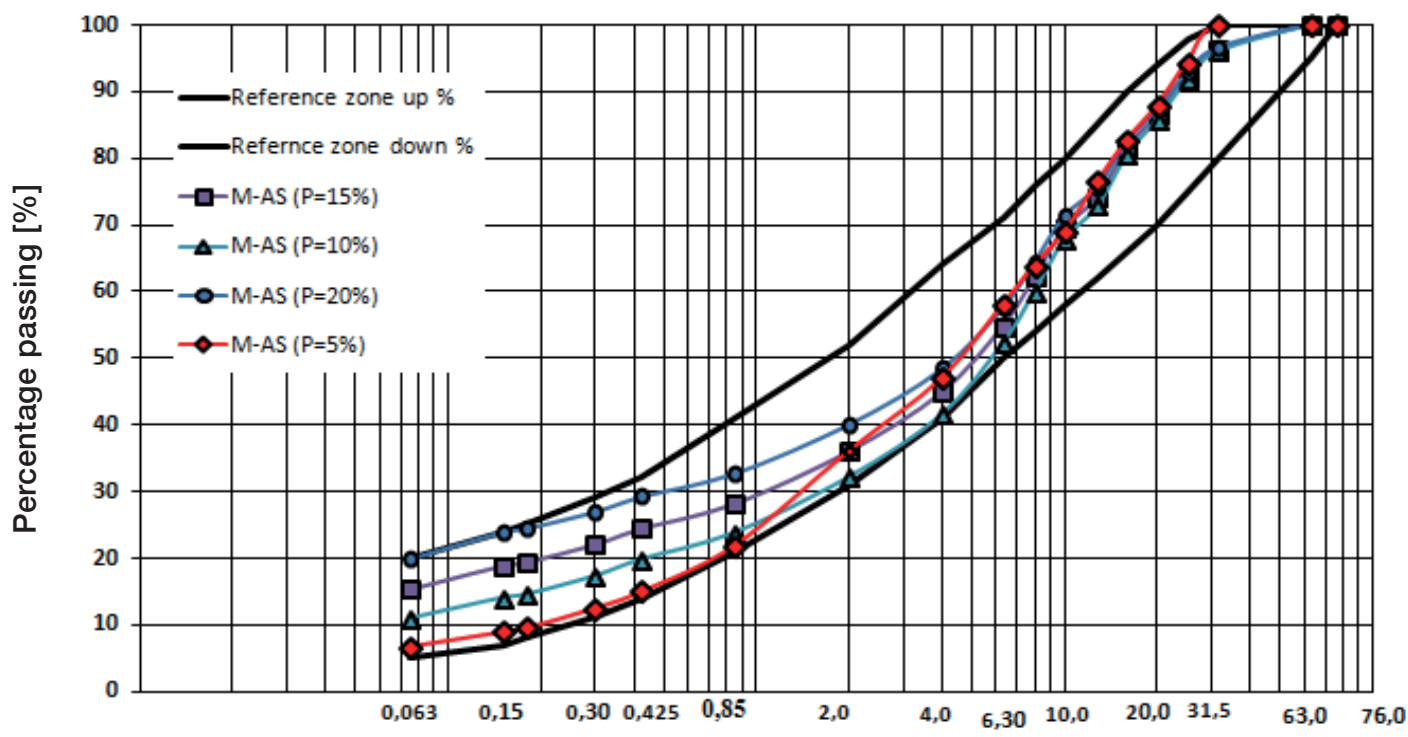

Particle size $[\mathrm{mm}]$

Fig. 5. Grading curves of the mineral mixtures of the recycled base course in relation to the gabbro dust content

dation improvement (Fig. 5). Foamed bitumen $80 \mathrm{~N}$ was used as a binder in the amounts of $3.0 \%, 3.5 \%, 4.0, \%$ and $4.5 \%$, and cement was added in the amount of $1.5 \%$. Final composition of the recycled base is shown in Table 1.

Table 1

Constituents of the recycled base layer with foamed bitumen

\begin{tabular}{|c|c|c|c|c|}
\hline \multirow[b]{2}{*}{ Component } & \multicolumn{4}{|c|}{ Percentage of components (\%) } \\
\hline & $\begin{array}{c}\mathrm{M}-\mathrm{AS} \\
(\mathrm{P}=5 \%)\end{array}$ & $\begin{array}{c}\mathrm{M}-\mathrm{AS} \\
(\mathrm{P}=10 \%)\end{array}$ & $\begin{array}{c}\mathrm{M}-\mathrm{AS} \\
(\mathrm{P}=15 \%)\end{array}$ & $\begin{array}{c}\mathrm{M}-\mathrm{AS} \\
(\mathrm{P}=20 \%)\end{array}$ \\
\hline $\begin{array}{l}\text { Reclaimed asphalt } \\
\text { pavement }\end{array}$ & 63.5 & 58.5 & 53.5 & 48.5 \\
\hline Aggregate $0 / 32$ & 30.0 & 30.0 & 30.0 & 30.0 \\
\hline Mineral dust (gabbro) & 5.0 & 10.0 & 15.0 & 20.0 \\
\hline $\begin{array}{l}\text { Portland cement } \\
\text { CEM I 32.5R }\end{array}$ & \multicolumn{4}{|c|}{1.5} \\
\hline Foamed asphalt 50/70 & \multicolumn{4}{|c|}{$3.0 \div 4.5$} \\
\hline
\end{tabular}

The grading curves of the mineral mixture for different contents of the gabbro dust are similar, starting in the regions of $4 \mathrm{~mm}$ fractions and up. For smaller fractions, the curves have varied plots, as a result of different amounts of the gabbro dust used.

To evaluate the effect of mineral dust on the properties of the recycled base course mineral mixtures with foamed bitumen, the testing program [13 24] was developed to determine:

- Air voids content, $\mathrm{V}_{\mathrm{m}}[\%]$, to the requirements of [25],

- Marshall stability, $\mathrm{S}[\mathrm{kN}]$, to the requirements of [26],
- Marshall stiffness, $\mathrm{Sz}[\mathrm{kN} / \mathrm{mm}]$, to the requirements of [26],

- Indirect Tensile Strength, ITS [MPa], to the requirements of [27],

- Stiffness modulus at $20^{\circ} \mathrm{C}, \mathrm{E}_{20^{\circ} \mathrm{C}}[\mathrm{MPa}]$, to the requirements of [28].

The testing program was implemented based on the experimental design with two factors, each on four levels. One of the main aims was to find a mathematical model that would explain the relationship between the output variable " $y$ " and input variables " $\mathrm{X}_{\mathrm{i}}$ " using a general formula. The results of the analysis [29-31] allowed for assuming that the most adequate model for this particular case was (1), represented as:

$$
\begin{aligned}
y & =b_{o}+\sum_{i=1}^{n} b_{o} \cdot X_{i}+\sum_{i=j=1}^{n} b_{i=j} \cdot X_{i} \cdot X_{j}+ \\
& +\sum_{i=1}^{n} b_{i i} \cdot X_{i}^{2} .
\end{aligned}
$$

The response surface of this model is a second-degree polynomial (2), which can be expressed as the following equation $[32,33]$ :

$$
\begin{aligned}
y & =b_{o}+b_{1} \cdot X_{1}+b_{2} \cdot X_{2}+b_{3} \cdot X_{1} \cdot X_{2}+ \\
& +b_{4} \cdot X_{1}^{2}+b_{4} \cdot X_{2}^{2},
\end{aligned}
$$

where:

$$
\begin{aligned}
\mathrm{X}_{1}- & \text { gabbro dust }(\mathrm{PG}) \text { content in the recycled mix- } \\
& \text { ture }[\%], \\
\mathrm{X}_{2}- & \text { foamed bitumen (AS) content in the recycled } \\
& \text { mixture }[\%], \\
\mathrm{b}_{0}-\mathrm{b}_{5}- & \text { experimental coefficients. }
\end{aligned}
$$




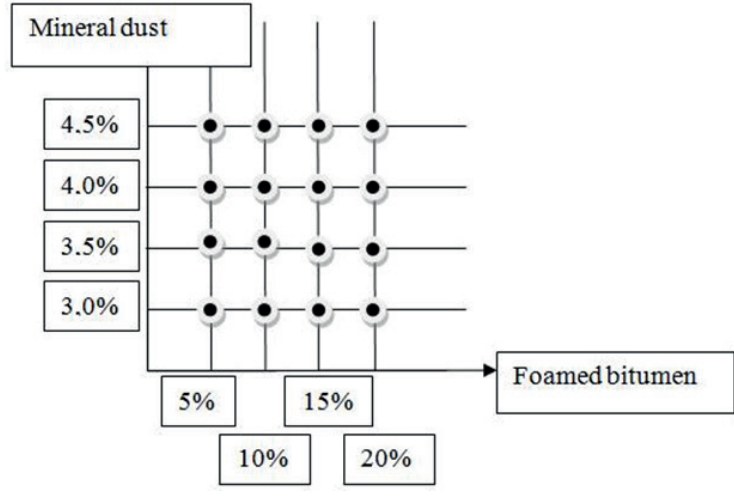

Fig. 6. Experimental design

A graphical representation of the experimental domain is presented in Fig. 6.

A utility function was used to determine the optimum amount of gabbro dust and foamed bitumen in the recycled mixture.

\section{Results}

The dependence of the recycled mixture properties $\mathrm{V}_{\mathrm{m}}, \mathrm{S}, \mathrm{Sz}$, ITS, $E_{20^{\circ} \mathrm{C}}$ on the amount of gabbro dust and foamed bitumen was evaluated using the models developed based on (2). The basic parameter that characterizes the properties of the recycled asphalt mixture is the air void content. This parameter has a considerable influence on the mechanical properties of the mixture, and on its resistance to the action of water. Statistical analysis software (General regression models module) was used to determine the parameter describing its relationship with the amount of gabbro dust and foamed bitumen in the recycled asphalt mixture (Table 2).

Table 2

Experimental coefficients for $\mathrm{V}_{\mathrm{m}}$ of the recycled mixture ( $\mathrm{Q}$ - quadratic form of the investigated attribute/variable, $\mathrm{L}$ - linear form of the investigated attribute)

\begin{tabular}{|c|c|c|}
\hline \multirow{2}{*}{ Factor } & \multicolumn{2}{|c|}{$\begin{array}{c}\text { Regr. coefficients Vm [\%]; } \\
\text { R-sqr }=0.82 ;\end{array}$} \\
& \multicolumn{2}{|c|}{ Adj: 0.73 MS residual =0.2 } \\
\cline { 2 - 3 } & $\begin{array}{c}\text { Regression } \\
\text { coefficent }\end{array}$ & p-value \\
\hline Mean/Interc. & -13.44 & 0.074 \\
(1) PG [\%] (L) & 0.21 & 0.280 \\
PG [\%] (Q) & 0.0026 & 0.586 \\
(2) AS [\%] (L) & $\mathbf{1 0 . 2 6}$ & $\mathbf{0 . 0 1 6}$ \\
AS [\%] (Q) & $-\mathbf{1 . 3 0}$ & $\mathbf{0 . 0 2 0}$ \\
1L by 2L & -0.04 & 0.308 \\
\hline
\end{tabular}

Using the regression approach in the analysis, the bolded values in the table indicate that a given factor is significant

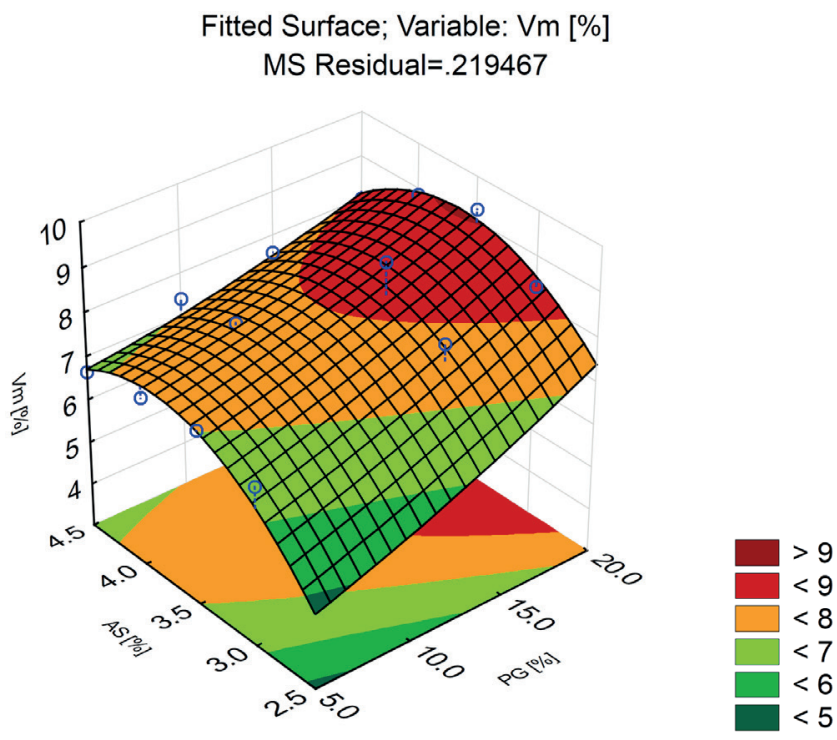

Fig. 7. Response surface for the variation in $\mathrm{V}_{\mathrm{m}}$ of the recycled mixture

(foamed bitumen) at the significance level of 0.05 for the air void content in the recycled material. It can be said that there is a strong influence of the foamed bitumen on void content parameter, with respect to the void fraction content parameter.

A graphical illustration of the model for the influence of the gabbro dust and foamed bitumen on the amount of air voids $\mathrm{V}_{\mathrm{m}}$ in the recycled mixture is presented in Fig. 7.

Analysis of void space indicates its increase with the increase in the amount of mineral dust in the recycled base course mixtures. Theoretically, the values of this parameter should decrease as the increased concentration of the fines provides greater packing in the blend. Most probably, the bitumen absorption capacity of mineral dust affects this relationship. The higher dust content in the recycled mixture causes the aggregation of air inside the dust structure and increases the amount of air voids in the base course. The study results for this parameter correspond to the results of the mineral dust characteristics determined theoretically (Fig. 7). The gabbro dust content turned out to be insignificant, but it does not mean that it should be omitted in the regression model.

The evaluation of the significance of the influence of the variables (gabbro dust, foamed bitumen) on air voids content included the ANOVA test (Table 3).

Table 3

Evaluation of statistical significance of factors' influence on $V_{m}$ of the recycled base course mixture with foamed bitumen (ANOVA)

\begin{tabular}{|c|c|c|c|c|c|}
\hline \multirow{2}{*}{ Factor } & \multicolumn{5}{|c|}{ ANOVA; Variable: Vm [\%]; } \\
\cline { 2 - 6 } & SS & df & MS & F & p \\
\hline (1) PG [\%] (L) & 7.887 & 1 & 7.888 & $\mathbf{3 5 . 9 3 7}$ & $<\mathbf{0 . 0 5}$ \\
PG [\%] (Q) & 0.070 & 1 & 0.070 & 0.3176 & 0.585 \\
(2) AS [\%] (L) & 0.005 & 1 & 0.005 & 0.0234 & 0.881 \\
AS [\%] (Q) & 1.682 & 1 & 1.688 & $\mathbf{7 . 6 6 6}$ & $\mathbf{0 . 0 2 0}$ \\
\hline
\end{tabular}




\begin{tabular}{|c|c|c|c|c|c|}
\hline \multirow{2}{*}{ Factor } & \multicolumn{5}{|c|}{ ANOVA; Variable: Vm [\%]; } \\
\cline { 2 - 6 } & SS & df & MS & F & $\mathrm{p}$ \\
\hline 1L by 2L & 0.253 & 1 & 0.253 & 1.152 & 0.308 \\
Error & 2.195 & 42 & 0.220 & & \\
Total SS & 12.092 & 47 & & & \\
\hline
\end{tabular}

SS - sum of squares,

MS - mean square within/between groups,

F - test statistic,

$\mathrm{p}$ - probability of obtaining a test statistic,

df - degree of freedom

Analysis of the statistical parameters summarized in Table 3 indicates that at the significance level $\mathrm{p}$-value $=0.05$, the significant influence on the content of air voids $\mathrm{V}_{\mathrm{m}}$ in the base course recycled mixture with foamed bitumen is emphasized by effects of the gabbro dust content ( $p$-value $<0.05$ ) and foamed bitumen content ( $\mathrm{p}$-value $=0.020)$.

Marshall stability is an important mechanical parameter that reflects the resistance of a mixture to permanent deformation. Table 4 presents the values of the coefficients in the model representing the influence of the gabbro dust and foamed bitumen on this property.

Table 4

Experimental coefficients for $\mathrm{S}$ of the recycled mixture

\begin{tabular}{|c|c|c|}
\hline \multirow[t]{2}{*}{ Factor } & \multicolumn{2}{|c|}{$\begin{array}{l}\text { Regr. coefficients } \mathrm{S}[\mathrm{kN}] \\
\mathrm{R} \text {-sqr }=0.67 \text {; Adj: } 0.50 \\
\quad \text { MS residual }=0.6\end{array}$} \\
\hline & Regression coefficent & p-value \\
\hline Mean/Interc. & 15.76 & 0.204 \\
\hline (1) PG $[\%]$ (L) & 0.049 & 0.04 \\
\hline PG [\%] (Q) & 0.0048 & 0.555 \\
\hline (2) AS $[\%](\mathrm{L})$ & -0.63 & 0.049 \\
\hline AS $[\%](Q)$ & -0.029 & 0.972 \\
\hline $1 \mathrm{~L}$ by $2 \mathrm{~L}$ & -0.013 & 0.843 \\
\hline
\end{tabular}

The response surface for this model is shown in Fig. 8.

Analysis of the results presented in Fig. 9 shows that Marshall stability increases with an increasing amount of gabbro dust in the mixture. At $15 \%$ of the gabbro dust content, the stability of the mixture has a very high value of more than $15 \mathrm{kN}$. The increase in the foamed bitumen content is favorable, though its impact intensity is less significant than that of the gabbro fines. It increases both factors and enhances the stability parameter of the cold recycled mixture. The ANOVA analysis (Table 5) confirms these relations.

The gabbro dust content has a significant effect on the Marshall stability of the mix, because p-value $=0.00651$, i.e. it is lower than the assumed significance level where $p$-value $\leq 0.05$. It can also be said that the effect of the foamed bitumen content invoked a significant influence on Stability (S) parameter (p-value $=0.0178)$.

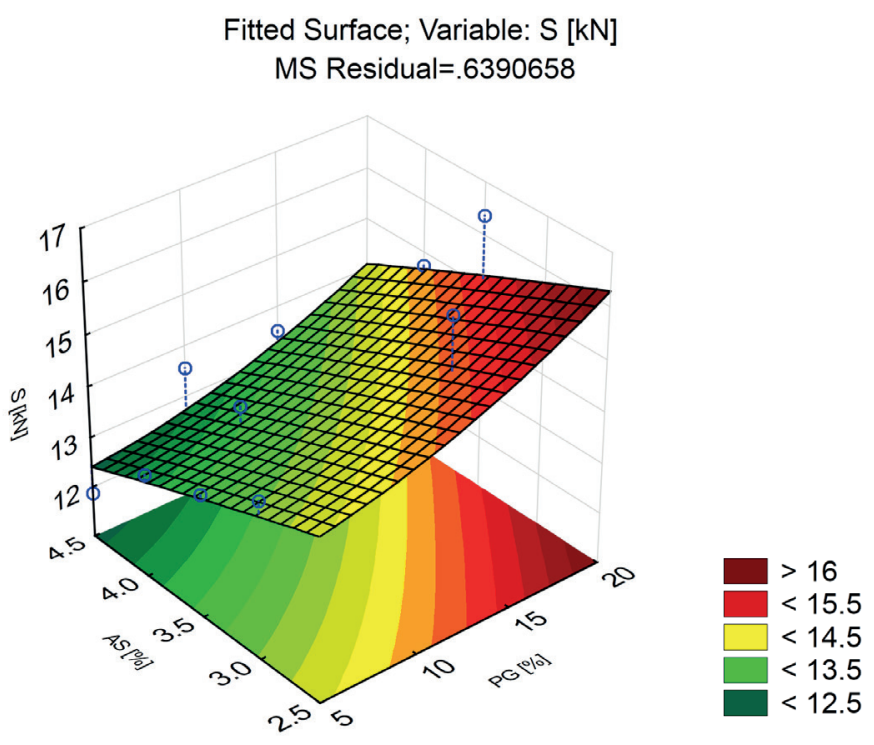

Fig. 8. Response surface for the variation in $\mathrm{S}$ of the recycled mixture

Fitted Surface; Variable: Sz [kN/mm] MS Residual $=.1408131$

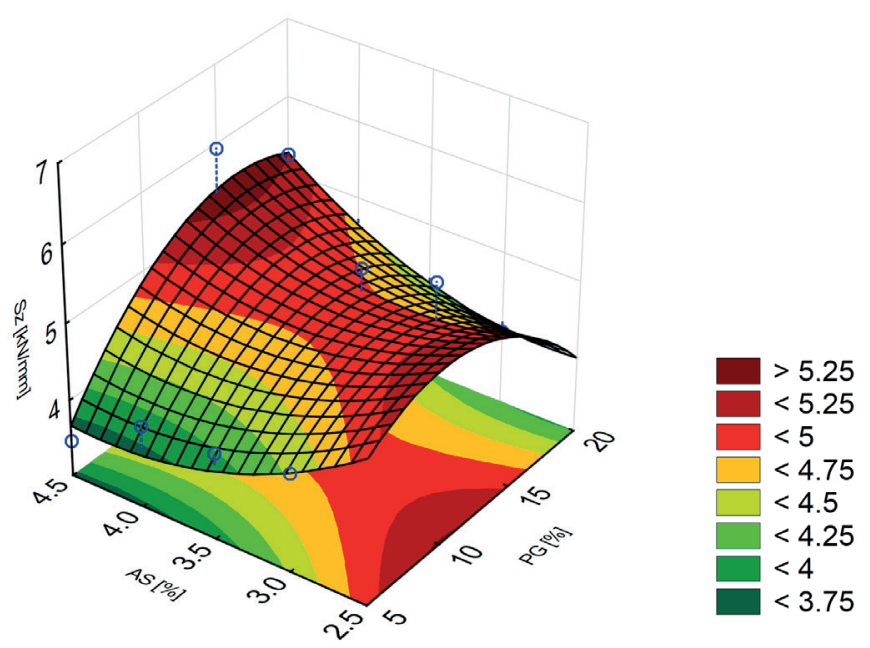

Fig. 9. Response surface for the variation in $\mathrm{Sz}$ of the recycled mixture

Table 5

Evaluation of statistical significance of factors' influence on $\mathrm{S}$ of the recycled base course mixture with foamed bitumen (ANOVA)

\begin{tabular}{|c|c|c|c|c|c|}
\hline \multirow{2}{*}{ Factor } & \multicolumn{5}{|c|}{ ANOVA of variable S [kN] } \\
\cline { 2 - 6 } & SS & df & MS & F & p \\
\hline (1) PG [\%] (L) & 7.488 & 1 & 7.488 & 11.717 & 0.007 \\
PG [\%] (Q) & 0.239 & 1 & 0.239 & 0.3734 & 0.555 \\
(2) AS [\%] (L) & 5.128 & 1 & 5.128 & 8.0247 & 0.0178 \\
AS [\%] (Q) & 0.00085 & 1 & 0.000854 & 0.00134 & 0.972 \\
1L by 2L & 0.0265 & 1 & 0.0265 & 0.0415 & 0.843 \\
Error & 6.391 & 42 & 0.639 & & \\
Total SS & 19.274 & 47 & & & \\
\hline
\end{tabular}


Table 6

Experimental coefficients for $\mathrm{Sz}$ of the recycled mixture

\begin{tabular}{|c|c|c|}
\hline \multirow{2}{*}{ Factor } & \multicolumn{2}{|c|}{ Regr. coefficients; Sz [kN/mm]; } \\
& \multicolumn{2}{|c|}{ R-sqr =0.76; } \\
& Adj: 0.63 MS residual = 0.14 \\
\cline { 2 - 3 } & Regression coefficient & p-value \\
\hline Mean/Interc. & $\mathbf{1 0 . 8 9}$ & $\mathbf{0 . 0 7 2}$ \\
(1) PG [\%] (L) & 0.071 & 0.642 \\
PG [\%](Q) & $\mathbf{- 0 . 0 1 4}$ & $\mathbf{0 . 0 0 4 6 5}$ \\
(2) AS [\%] (L) & -3.82 & 0.210 \\
AS [\%](Q) & 0.40 & 0.315 \\
1L by 2L & $\mathbf{0 . 0 8 3}$ & $\mathbf{0 . 0 1 9 4}$ \\
\hline
\end{tabular}

The Marshall stiffness Sz allows for determining the resistance of the recycled base mix to permanent deformation. This parameter expresses the deformation of the recycled material in relation to its stability. The values of experimental coefficients of the model built using Statistica software are summarized in Table 6.

The model for the influence of the amounts of gabbro dust and foamed bitumen revealed a significant influence of some components in the full model. There is a strong influence of non-linear component represented by gabbro dust amount and the interaction between the amounts of gabbro dust and foamed bitumen.

The response surface of the model for the relationship between the contents of gabbro dust and foamed bitumen, and the Marshall quotient/stiffness value is presented in Fig. 9.

Analysis of the results shown in Fig. 9 indicates that the Marshall stiffness increases when the concentration of the gabbro dust increases at high foamed bitumen content. This interaction, however, becomes significant at higher concentrations of these agents ( $\mathrm{AS}>4.0 \%$ and $\mathrm{PG}>15 \%$ ). As mentioned before, an interaction is observed between the foamed bitumen and gabbro dust, in terms of increasing the Marshall stiffness of the recycled base course mixture, which has been confirmed in the analysis of significance, performed using the ANOVA test (Table 7).

Table 7

Evaluation of statistical significance of factors' influence on $\mathrm{Sz}$ of the recycled base course mixture with foamed bitumen (ANOVA)

\begin{tabular}{|c|c|c|c|c|c|}
\hline \multirow{2}{*}{ Factor } & \multicolumn{5}{|c|}{ ANOVA of variable Sz [kN/mm] } \\
\cline { 2 - 6 } & SS & df & MS & F & p \\
\hline (1) PG [\%] (L) & 0.950 & 1 & 0.950 & $\mathbf{6 . 7 4 3}$ & $\mathbf{0 . 0 2 7}$ \\
PG [\%] (Q) & 1.850 & 1 & 1.850 & $\mathbf{1 3 . 1 3 8}$ & $\mathbf{0 . 0 0 5}$ \\
(2) AS [\%] (L) & 0.217 & 1 & 0.218 & 1.547 & 0.242 \\
AS [\%] (Q) & 0.157 & 1 & 0.158 & 1.119 & 0.315 \\
1L by 2L & 1.088 & 1 & 1.088 & $\mathbf{7 . 7 2 6}$ & $\mathbf{0 . 0 2 0}$ \\
Error & 1.408 & 42 & 0.141 & & \\
Total SS & 5.671 & 47 & & & \\
\hline
\end{tabular}

Flexural tensile stresses act on the pavement structure, and thus, it is very important to define this characteristic for the recycled material with gabbro dust and foamed bitumen in the base course. Table 8 compiles the parameters of the model for the effect of gabbro dust and foamed bitumen on the indirect tensile strength ITS of the investigated material.

Table 8

Experimental coefficients for ITS of the recycled mixture

\begin{tabular}{|c|c|c|}
\hline \multirow[t]{2}{*}{ Factor } & \multicolumn{2}{|c|}{$\begin{array}{l}\text { Regr. coefficients; ITS }[\mathrm{kPa}] \\
\text { R-sqr }=0.53 ; \text { Adj: } 0.30 \\
\text { MS residual }=2222.0\end{array}$} \\
\hline & Regression coefficient & $\mathrm{p}$-value \\
\hline Mean/Interc. & -1010.93 & 0.168 \\
\hline (1) PG [\%] (L) & 7.94 & 0.677 \\
\hline PG [\%] (Q) & 0.08 & 0.863 \\
\hline (2) AS [\%] (L) & 919.74 & 0.028 \\
\hline AS [\%] (Q) & -111.68 & 0.039 \\
\hline $1 \mathrm{~L}$ by $2 \mathrm{~L}$ & -2.76 & 0.481 \\
\hline
\end{tabular}

The response surface of the model for the dependence of ITS on the amounts of gabbro dust and foamed bitumen is shown in Fig. 10.

The evaluation of the ITS study results indicates that all the recycled base course mixtures have reached the recommended value of $500 \mathrm{kPa}$ [24]. It has to be noted that the increased amount of foamed bitumen leads to a rapid increase in the ITS value. The intensity of this process is higher than that with the increased gabbro dust content. Higher amounts of gabbro dust used increase the stiffness modulus of the recycled mixture, and have a detrimental effect on its indirect tensile strength.

\section{Fitted Surface; Variable: ITS [kPa] MS Residual $=2221.986$ DV: ITS [kPa]}

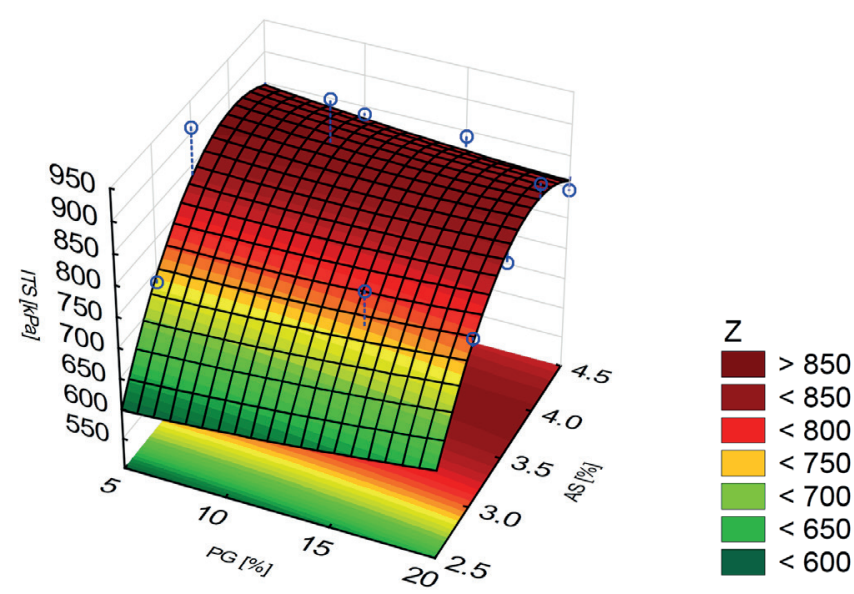

Fig. 10. Response surface for the variation in ITS of the recycled mixture 
The highest average value of ITS parameter, approximately $850-900 \mathrm{kPa}$, has been reached at $5 \%$ gabbro dust content and with $4.0 \%$ foamed bitumen content.

The in-depth statistical analysis of the influence of the investigated factors (amounts of gabbro dust and foamed bitumen) on the ITS value of the recycled mixture was carried out using the significance test in ANOVA (Table 9).

Table 9

Evaluation of statistical significance of factors' influence on ITS of the recycled base course mixture with foamed bitumen (ANOVA)

\begin{tabular}{|c|c|c|c|c|c|}
\hline \multirow{2}{*}{ Factor } & \multicolumn{5}{|c|}{ ANOVA of variable ITS [kPa] } \\
\cline { 2 - 6 } & SS & df & MS & F & p \\
\hline (1) PG [\%] (L) & 50.41 & 1 & 50.41 & 0.023 & 0.883 \\
PG [\%] (Q) & 69.63 & 1 & 69.63 & 0.031 & 0.863 \\
(2) AS [\%] (L) & 11359.46 & 1 & 11359.46 & $\mathbf{5 . 1 1 2}$ & $\mathbf{0 . 0 4 7}$ \\
AS [\%] (Q) & 12471.95 & 1 & 12471.95 & $\mathbf{5 . 6 1 3}$ & $\mathbf{0 . 0 3 9}$ \\
1L by 2L & 1189.91 & 1 & 1189.91 & 0.536 & 0.481 \\
Error & 22219.86 & 42 & 2221.99 & & \\
Total SS & 47361.23 & 47 & & & \\
\hline
\end{tabular}

The analysis of the statistical parameters confirms the positive influence of the foamed bitumen on the indirect tensile strength ITS of the recycled base mix.

Considering that the stiffness modulus at $20^{\circ} \mathrm{C}\left(\mathrm{E}_{20^{\circ} \mathrm{C}}\right)(28)$, determined at 28 days, is the basic asphalt mix characteristic taken into account in the mechanistic design of the pavement structure thickness, the effect of the gabbro dust on this parameter is critical. The values of experimental coefficients determined in the study, as well as the statistical evaluation results, are presented in Table 10.

Table 10

Experimental coefficients for $\mathrm{E}_{20^{\circ} \mathrm{C}}$ of the recycled mixture

\begin{tabular}{|c|c|c|}
\hline \multirow{2}{*}{ Factor } & \multicolumn{2}{|c|}{ Regr. coefficients; $\mathrm{E}_{20^{\circ} \mathrm{C}}\left(\mathrm{E}_{20 \text { deg.C }}\right)[\mathrm{MPa}] ;$} \\
& R-sqr $=0.81 ;$ Adj: 0.71 & $\mathrm{MS}$ residual = 55187.9 \\
\cline { 2 - 3 } & Regression coefficient & p-value \\
\hline Mean/Interc. & -5335.96 & 0.146 \\
(1) PG [\%] (L) & -148.94 & 0.138 \\
PG [\%] (Q) & 2.31 & 0.348 \\
(2) AS [\%] (L) & $\mathbf{5 6 0 6 . 4 3}$ & $\mathbf{0 . 0 1 0}$ \\
AS [\%] (Q) & $-\mathbf{7 7 5 . 2 1}$ & $\mathbf{0 . 0 0 8}$ \\
1L by 2L & 36.85 & 0.0783 \\
\hline
\end{tabular}

The model of the response surface of the recycled mixture in terms of the amounts of gabbro dust and foamed bitumen is presented in Fig. 11.

The analysis of the study results for the stiffness modulus $\mathrm{E}_{20^{\circ} \mathrm{C}}$ of the recycled mixture indicates that the influence of the foamed bitumen on the stiffness modulus value is significant. The stiffness modulus increases with the high concentration
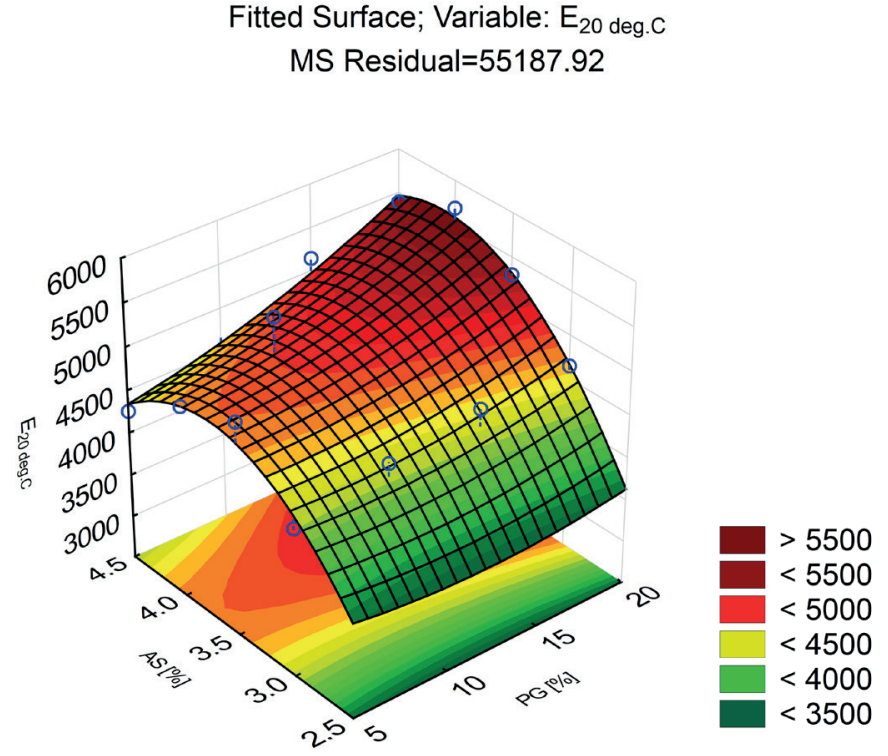

Fig. 11. Response surface for the variation in $\mathrm{E}_{20^{\circ} \mathrm{C}}$ of the recycled mixture

of the gabbro dusts, reaching the value of $\mathrm{E}_{20^{\circ} \mathrm{C}}>5500 \mathrm{MPa}$. This happened when the dust content in the mixture was within the range from 15 to $20 \%$. An increase in the foamed bitumen content permanently reduces stiffness modulus $\mathrm{E}_{20^{\circ} \mathrm{C}}$ of the mixture. The presence of foamed bitumen brings a plastic behavior.

The statistical analysis of the effect of gabbro dust and foamed bitumen amounts on $\mathrm{E}_{20^{\circ} \mathrm{C}}$ of the recycled mixture was carried out using the significance test in ANOVA (Table 11).

Table 11

Evaluation of statistical significance of factors' influence on $\mathrm{E}_{20^{\circ} \mathrm{C}}$ of the recycled mixture with foamed bitumen (ANOVA)

\begin{tabular}{|c|c|c|c|c|c|}
\hline \multirow{2}{*}{ Factor } & \multicolumn{5}{|c|}{ ANOVA of variable $\mathrm{E}_{20^{\circ} \mathrm{C}}\left(\mathrm{E}_{20 \mathrm{degC}}\right)$} \\
\cline { 2 - 6 } & $\mathrm{SS}$ & $\mathrm{df}$ & $\mathrm{MS}$ & $\mathrm{F}$ & $\mathrm{p}$ \\
\hline PG [\%] (L) & 1110344 & 1 & 1110344 & $\mathbf{2 0 . 1 2}$ & $\mathbf{0 . 0 0 1}$ \\
PG [\%] (Q) & 53573 & 1 & 53573 & 0.98 & 0.348 \\
AS [\%] (L) & 320150 & 1 & 320150 & $\mathbf{5 . 8 0}$ & $\mathbf{0 . 0 3 7}$ \\
AS [\%] (Q) & 600948 & 1 & 600948 & $\mathbf{1 0 . 8 9}$ & $\mathbf{0 . 0 0 8}$ \\
1L by 2L & 212221 & 1 & 212221 & 3.85 & 0.078 \\
Error & 551879 & 42 & 55188 & & \\
Total SS & 2849116 & 47 & & & \\
\hline
\end{tabular}

The analysis of significant factors using ANOVA, (gabbro dusts, foamed bitumen) confirms a fairly significant effect of gabbro dust on the stiffness modulus $\mathrm{E}_{20^{\circ} \mathrm{C}}$. The $\mathrm{p}$-value $=0.001$ is less than the required $p$-value of 0.05 . Foamed bitumen has a significant effect on this parameter as well. A lack of an interaction between the gabbro dust and foamed bitumen in terms of the stiffness modulus has also been confirmed. 
To determine the gabbro dust and foamed bitumen amounts that will provide the optimal properties of the recycled base mixture, Harrington's utility function [34] was used, expressed by (3):

$$
U^{I I I}=\exp \left[-\exp \sum_{i=1}^{m} w_{i} \cdot\left(\frac{y^{(i)}-y_{G^{(i)}}}{y_{L^{(i)}}-y_{G^{(i)}}}\right)\right],
$$

where:

$$
\begin{aligned}
& y^{(i)}-\text { properties of the recycled mixture with dusts, } \\
& y_{L^{(i)}}-\text { worst value of the } i \text {-th property being investigated, } \\
& y_{G^{(i)}}-\text { best value of the } i \text {-th property being investigated, } \\
& w_{i}-\text { weights assigned to individual properties } y^{(i)}, \\
& 0 \leq w_{i} \leq 1, \quad \quad \mathrm{I}=1,2, \ldots, m, \quad \sum_{i=1}^{m} w_{i}=1 .
\end{aligned}
$$

Utility $U_{i}^{I I I}$ gives a value within the range $(0 ; 1)$. The numbers close to 0 correspond to particularly disadvantageous values of $y^{(i)}$, whereas those close to 1 correspond to the most advantageous values. The set of $y^{(i)}$ values which are considered satisfactory is converted into a range from 0.368 to 0.692 [35].

The optimization process was divided into two steps. The first step was focused on reaching a high stiffness modulus of the recycled mixture. Parameters such as stiffness modulus $\mathrm{E}_{20^{\circ} \mathrm{C}}$ and Marshall stability were set with a double weight in relation to the remaining parameters. The most important stage of the optimization process is to establish a criteria for all parameters. The required ranges, assigned to the criteria of the variables, were constructed based on the information included in [36, 37]. The criteria are summarized in Table 12.

Table 12

Criteria used in the optimization for the first step

\begin{tabular}{|c|c|c|c|c|c|}
\hline Value level & $\begin{array}{c}\mathrm{E}_{20}{ }^{\circ} \mathrm{C} \\
{[\mathrm{MPa}]}\end{array}$ & $\begin{array}{c}\mathrm{Vm} \\
{[\%]}\end{array}$ & $\begin{array}{c}\mathrm{ITS} \\
{[\mathrm{MPa}]}\end{array}$ & $\begin{array}{c}\mathrm{S} \\
{[\mathrm{kN}]}\end{array}$ & $\begin{array}{c}\mathrm{Sz} \\
{[\mathrm{kN} / \mathrm{mm}]}\end{array}$ \\
\hline better & 2500 & 12 & 1600 & 20 & 5 \\
worse & 500 & 5 & 700 & 8 & 2 \\
weight & 0.29 & 0.14 & 0.14 & 0.29 & 0.14 \\
\hline
\end{tabular}

Then, Statistica software was used to calculate the components of the Harrington function for each criterion of the recycled base course mixture (Fig. 12).

The "good" optimization results, according to Harrington's desirability function, represent values $\mathrm{U}^{\mathrm{III}}$ greater than 0.63 . Based on the analysis results, the gabbro dust quantities from $15 \%$ to $20 \%$ and foamed bitumen quantities of approximately $3.5 \%$ (determined value $3.375 \%$ ), were found to provide the optimum values of the recycled mixture parameters. Such mixtures will reveal a high stiffness modulus at an acceptable level of void contents $\left(\mathrm{V}_{\mathrm{m}}\right)$ and indirect strength ratio (ITS).

The second step was focused on highlighting the best results for ITS and $V_{m}$ parameters. For this case, the criteria are as follows (Table 13), and the distribution of results is presented in Fig. 13.

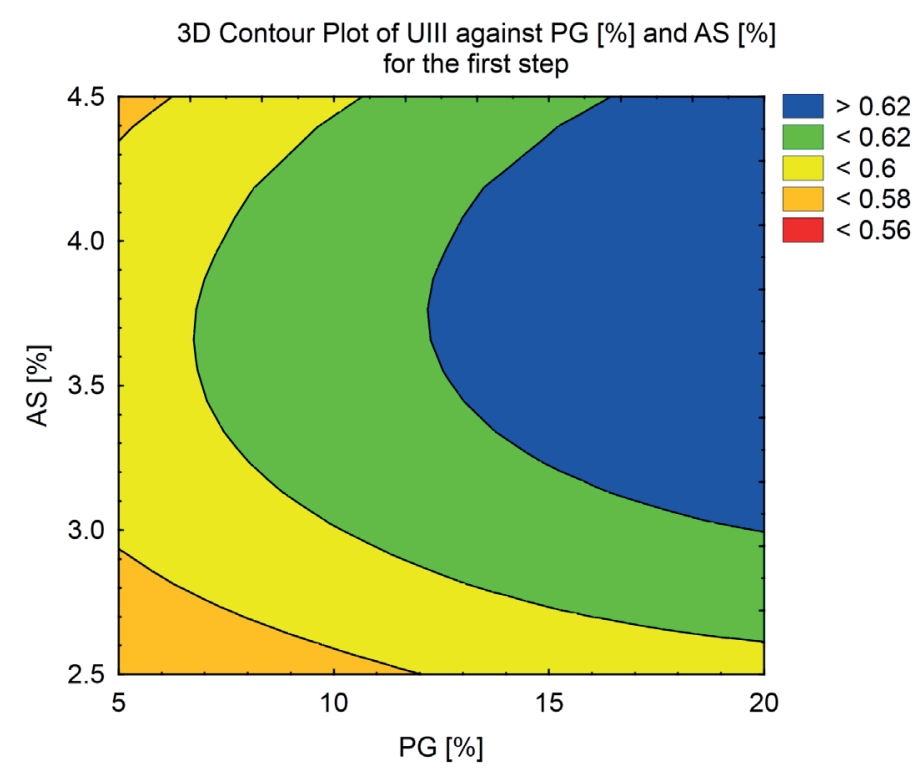

Fig. 12. Contour plot of desirability function $\left(\mathrm{U}^{\mathrm{III}}\right)$ for two factors of the recycled base course mixture for the first step

Table 13

Criteria used in the optimization for the second step

\begin{tabular}{|l|l|l|l|l|l|}
\hline Value level & $\begin{array}{l}\mathrm{E}_{20^{\circ} \mathrm{C}}[\mathrm{MPa}] \\
\text { better }\end{array}$ & $\begin{array}{l}\mathrm{Vm} \\
{[\%]}\end{array}$ & $\begin{array}{l}\mathrm{ITS} \\
{[\mathrm{MPa}]}\end{array}$ & $\begin{array}{l}\mathrm{S} \\
{[\mathrm{kN}]}\end{array}$ & $\begin{array}{l}\mathrm{Sz} \\
{[\mathrm{kN} / \mathrm{mm}]}\end{array}$ \\
worse & 2500 & 12 & 1600 & 20 & 5 \\
weight & 500 & 5 & 700 & 8 & 2 \\
\hline
\end{tabular}

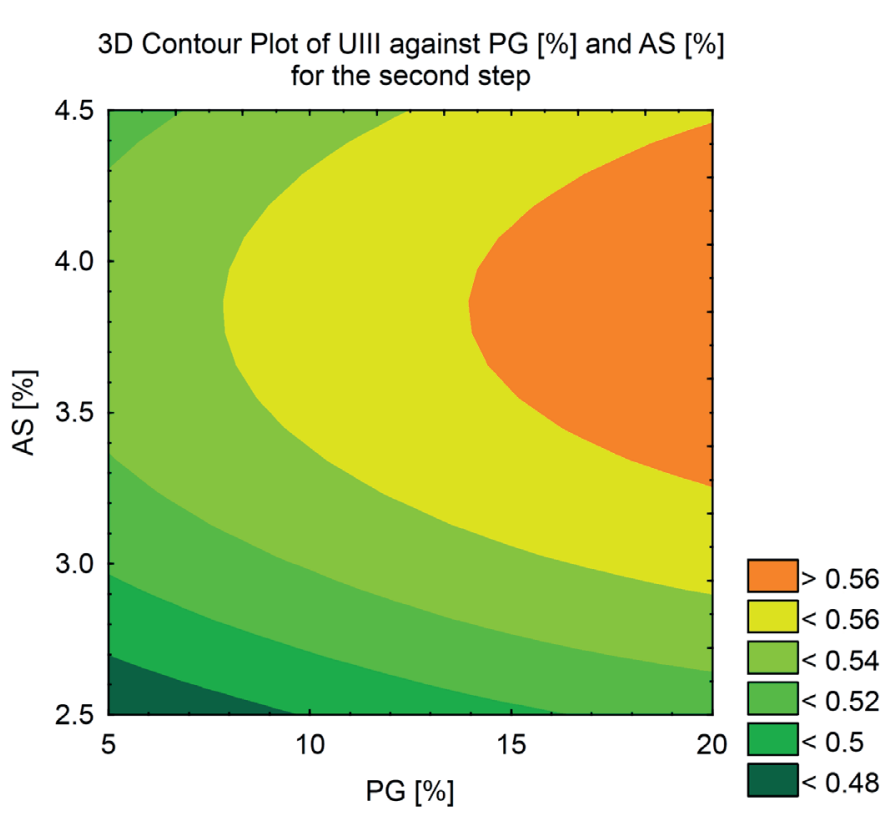

Fig. 13. Contour plot of the desirability function $\left(\mathrm{U}^{\mathrm{III}}\right)$ for two factors of the recycled base course mixture for the second step 
Statistica software was used to calculate the components of the Harrington function for each criterion of the recycled base course mixture (Fig. 13).

For this optimization variant, similarly to previous results, the optimal content of foamed bitumen was determined to be in range between 3.5 to $4.0 \%$, and for gabbro dust content to be greater than $15 \%$. It should be noted that for these two optimization steps for achieving the optimal ranges of results, overlapped in the majority. Finally, the optimal amount of foamed bitumen is approximately $3.5 \%$. For such a bitumen content it is possible to apply more that $15 \%$ of the gabbro dust. Considered the optimal combination of compounds, it guarantees an increase in whole stiffness of the recycled mixture, as well as an increase in its cohesion. Both factors, at optimal content, can beneficially decrease the plastic strains in subgrade, as it was mentioned in [38].

\section{Conclusion}

The following conclusions can be reached based on the laboratory tests results for determining the relationship between the durability of the recycled asphalt base course mixtures and the amounts of gabbro dust and foamed bitumen added to the blends:

1. For the mineral dusts to be used in cold recycling of pavements with foamed bitumen, it is necessary to identify their structural and functional properties, including the $\mathrm{pH}$ number, clay fraction content, and bitumen absorption.

2. The application of gabbro fines differently improves the mechanical characteristics of the recycled base mixture, that is, Marshall stability, Marshall stiffness and indirect tensile strength ITS, highly enhancing the resistance of the pavement structure to permanent deformation.

3. Gabbro dusts provide a higher stiffness modulus (ANOVA analysis) of the recycled base mixture at $20^{\circ} \mathrm{C}$, contributing to the reduction in the pavement structural thickness (mechanistic method), retaining its durability.

4. The use of gabbro dust in the cold recycling technology with foamed bitumen will provide the opportunity to utilize considerable quantities of the fines, contributing greatly to proper mineral resources management and environmental protection.

5. The best result, in terms of a high recycled mixture's whole stiffness, was attained at approximately $3.5 \%$ foamed bitumen and a gabbro dust content ranging from 15 to $20 \%$.

The results obtained from the study indicate a potential for a wide array of applications of mineral fines, in particular those alkaline in character, derived from the dry dust extraction operations conducted at the quarry sites and the asphalt mixing plants, to cold recycling of asphalt mixes with foamed bitumen.

Acknowledgments. This research has been carried out as part of theproject entitled "Innovative resources and effective methods of safety improvement and durability of buildings and transport infrastructure in the sustainable development" financed by the European Union from the European Fund of Regional Development based on the Operational Program of the Innovative Economy.

\section{REFERENCES}

[1] U. Kołodziejczyk, M. Ćwiąkała, and A. Widuch, "Use of flay-ash for the production of hydraulic binding agents and for soil stabilization", Mineral Resources Management 28 (4), doi: 10.2478/v10269-012-0036-9, 15-28 (2012), [in Polish].

[2] J. Pachowski, "Development of the technology of creation of power plant by-products and their description and possible uses in road construction technologies", Roads and Bridges 1, 59-99 (2002).

[3] D. Sybilski and C. Kraszewski, "Evaluation and testing of selected industrial wastes for use in road structures", IBDiM, Warsaw, 2004.

[4] M. Iwański and A. Chomicz-Kowalska, "Evaluation of the pavement performance", Bull. Pol. Ac.: Tech 63 (1), doi: 10.1515/bpasts-2015-0011, 97-105 (2015).

[5] "Kruszywa do mieszanek mineralno-asfaltowych i powierzchniowych utrwaleń na drogach krajowych", WT-1 2010. Wymagania Techniczne, GDDKiA, Warszawa, 2010, [in Polish].

[6] "Kruszywa do mieszanek bitumicznych i powierzchniowych utrwaleń stosowanych na drogach, lotniskach i innych powierzchniach przeznaczonych do ruchu", PN-EN 13043:2002, [in Polish].

[7] M. Iwański, "Właściwości mieszanki mineralno-asfaltowej a rodzaj kruszywa" Drogownictwo 6, 185-195 (2004), [in Polish].

[8] J. Piłat and P. Radziszewski, "Nawierzchnie asfaltowe", WKŁ, Warszawa, 2007, [in Polish].

[9] W. Grabowski, J. Wilanowicz, M. Słowik, and T. Soból, “Assessment of the stiffening properties of mineral fillers obtained from a dust extractor installed in an asphalt plant", Proceedings of $3^{\text {rd }}$ International Conference on Modern Technologies in Highway Engineering, Wydawnictwo Politechniki Poznańskiej, 299-309 (2005).

[10] E. Vogt, D. Hołownia, "Study of hydrophobic properties of lime dust”, Mineral Resources Management 26 (2), 41-56 (2010).

[11] M. Iwański, P. Buczyński, "Sposób głębokiego recyklingu konstrukcji nawierzchni w technologii asfaltu spienionego", Patent No. PL A1 396497, Polska, 2013, [in Polish].

[12] Y. Kim, H.D. Lee, "Development of a mixture design process for cold-in place rehabilitation using foamed asphalt. Final report for TR-474 phase 1”, University of Iowa, 2003

[13] „Warunki techniczne wykonania warstwy podbudowy z mieszanki mineralno-cementowo-emulsyjnej (MCE) ", Informacje, Instrukcje I (61), IBDiM, Warszawa, 1999, [in Polish].

[14] D. Sybilski, J. Kukiełka, "Rheological properties of mineral cement-emulsion (MCE) mixtures on the basis of the master curve", I Polski Kongres Drogowy, Warszawa, 461-468 (2006).

[15] M. Iwański, A. Chomicz-Kowalska, "Laboratory study on mechanical parameters of foamed bitumen mixtures in the cold recycling technology", Proceedings of $11^{\text {th }}$ International Conference on Modern Building Materials, Structure and Techniques 57, doi: 10.1016/j.proeng.2013.04.56, 433-442 (2013).

[16] H. Gui-Ping, W. Wing Gun, "Effects of moisture on strength and permanent deformation of foamed asphalt mix incorporating RAP materials", Construction and Building Materials 22 (1), 30-40 (2008). 
[17] W. Grabowski, "Struktura a właściwości funkcjonalne wypełniaczy mineralnych stosowanych w drogownictwie", Poznań University of Technology Press, Poznań, 2007, [in Polish].

[18] "Metody badania cementu. Oznaczenie stopnia zmielenia", PN-EN 196-6:1997, [in Polish].

[19] "Badania geometrycznych właściwości kruszyw. Ocena zawartości drobnych cząstek. Badanie błękitem metylowym”, PN-EN 933-9:2001, [in Polish].

[20] "Badanie mechanicznych i fizycznych właściwości kruszyw. Oznaczenie pustych przestrzeni suchego, zagęszczonego wypełniacza", PN-EN 1097-4:2002, [in Polish].

[21] "Badania kruszyw wypełniających stosowanych do mieszanek bitumicznych. Liczba bitumiczna", PN-EN 13179-2, [in Polish].

[22] K.J. Jenkins, "Mixture design considerations for cold and halfwarm bituminous mixtures with emphasis on foamed bitumen", $\mathrm{PhD}$ dissertation, University of Stellenbosch, South Africa, 2000.

[23] M. Iwański, A. Chomicz, "Przydatność do spieniania asfaltów drogowych stosowanych w Polsce", Drogownictwo 8, 267-271 (2006), [in Polish].

[24] "Wirtgen cold recycling manual", Wirtgen GmbH, Windhagen, Germany, 2012.

[25] "Mieszanki mineralno-asfaltowe. Metody badań mieszanek mineralno-asfaltowych na gorąco. Oznaczanie zawartości wolnej przestrzeni”, PN-EN 12697-8:2005, [in Polish].

[26] "Mieszanki mineralno-asfaltowe, Metody badań mieszanek mineralno-asfaltowych na gorąco. Badanie Marshalla”, PN-EN 12697-34:2012, [in Polish].

[27] "Mieszanki mineralno-asfaltowe. Metody badań mieszanek mineralno-asfaltowych na gorąco. Odporność mieszanek mineralno-asfaltowych na rozciąganie pośrednie", PN-EN 12697-23:2009, [in Polish].
[28] "Bituminous mixtures. Test methods for hot mix asphalt. Stiffness: Annex C - Test applying indirect tension to cylindrical specimens (IT-CY) ", PN-EN 12697-26: Annex C, 2012.

[29] D.G. Montgomery, Design and Analysis of Experiments, 5th Edition, John Wiley and Sons, 2001.

[30] M. Iwański, G. Mazurek, "Structuring role of F-T synthetic wax in bitumen", Bull. Pol. Ac.: Tech. 62 (3), doi: 10.2478/bpasts-2014-0057, 525-534 (2014).

[31] L. Czarnecki, J.J. Sokołowska, "Material model and revealing the truth", Bull. Pol. Ac.: Tech. 63 (1), doi: 10.1515/bpasts-2015-0001, 7-14 (2015).

[32] L. Czarnecki, P. Woyciechowski, "Modelling of concrete carbonation: is it a process unlimited in time and restricted in space?", Bull. Pol. Ac.: Tech. 63 (1), doi: 10.1515/bpasts-2015-0006, 43-54 (2015).

[33] Z. Piasta, A. Lenarcik, "Applications of statistical multi-criteria optimisation in design of concretes", in Optimization Methods for Material Design of Cement-based Composites, pp.150-166, ed. A.M. Brandt, E \& FN Spon, London, 1998.

[34] E.C. Harrington, "The desirability function", Industrial Quality Control 21, 494-498 (1965).

[35] L. Zivorad, Design of Experiments in Chemical Engineering, WILEY-VCH, 2004.

[36] "Katalog wzmocnień i remontów nawierzchni podatnych i półsztywnych", in KTKNPiP, GDDKiA, Poland, 2012, [in Polish].

[37] B. Dołżycki, "Instrukcja projektowania i wbudowywania mieszanek mineralno-cementowo-emulsyjnych (MCE) ", GDDKiA, Gdańsk, 2013, [in Polish].

[38] Gonzalez, A. A. (2012). An Experimental Study of the Deformational and Performance Characteristics of Foamed Bitumen Stabilised Pavements, PhD Dissertation, University of Canterbury, New Zealand. 